\title{
Phenolic Composition and Antioxidant and Antiproliferative Activities of the Extracts of Twelve Common Bean (Phaseolus vulgaris L.) Endemic Ecotypes of Southern Italy before and after Cooking
}

\author{
Maria Neve Ombra, ${ }^{1}$ Antonio d'Acierno, ${ }^{1}$ Filomena Nazzaro, ${ }^{1}$ \\ Riccardo Riccardi, ${ }^{2}$ Patrizia Spigno, ${ }^{2}$ Massimo Zaccardelli, ${ }^{3}$ Catello Pane, ${ }^{3}$ \\ Mena Maione, ${ }^{1}$ and Florinda Fratianni ${ }^{1}$ \\ ${ }^{1}$ Institute of Food Science, CNR-ISA, Via Roma 64, 83100, Avellino, Italy \\ ${ }^{2}$ Azienda "F. Marsocci", Via Varignano 7, 80011 Acerra, Italy \\ ${ }^{3}$ CREA, Via dei Cavalleggeri 25, 84098 Pontecagnano, Italy
}

Correspondence should be addressed to Filomena Nazzaro; mena@isa.cnr.it

Received 23 September 2016; Accepted 25 October 2016

Academic Editor: Ilaria Peluso

Copyright (C) 2016 Maria Neve Ombra et al. This is an open access article distributed under the Creative Commons Attribution License, which permits unrestricted use, distribution, and reproduction in any medium, provided the original work is properly cited.

\begin{abstract}
Beans are important dietary components with versatile health benefits. We analysed the extracts of twelve ecotypes of Phaseolus vulgaris in order to determine their phenolic profiles, antioxidant activity, and the in vitro antiproliferative activity. Ultraperformance liquid chromatography with diode array detector (UPLC-DAD) admitted us to detect and quantify some known polyphenols, such as gallic acid, chlorogenic acid, epicatechin, myricetin, formononetin, caffeic acid, and kaempferol. The antioxidant activity (AA) ranged from $1.568 \pm 0.041$ to $66.572 \pm 3.197 \mathrm{mg}$ necessary to inhibit the activity of the 2,2-diphenyl-1picrylhydrazyl $(\mathrm{DPPH})$ radical by $50 \%\left(\mathrm{EC}_{50}\right)$. The extracts, except those obtained from the nonpigmented samples, were capable of inhibiting the proliferation of the human epithelial colorectal adenocarcinoma (Caco-2) cells, human breast cancer cells MCF-7, and A549 NSCLC cell line. Cultivars differed in composition and concentration of polyphenols including anthocyanins; cooking affected the antioxidant activity only marginally. Qualitative and quantitative differences in phenolic composition between the groups of beans influenced the biological activities; on the other hand, we did not find significant differences on the biological activities within the same variety, before and after cooking.
\end{abstract}

\section{Introduction}

Among legumes, common beans (Phaseolus vulgaris L.) are widely consumed throughout the world. They play a significant role in human nutrition, being an important source of plant proteins, minerals, and certain vitamins and exhibit, for this reason, high nutritional value. In last years, bioactive effects, associated with the fibres, polyphenols, and other beans components related to human health have gained attention $[1,2]$. Beans contain substantial amount of phenolic acids and flavonoids; some cultivars (red, black, and blue-violet coloured beans) show also anthocyanins, such as delphinidin and cyanidin, that overall attribute them a very strong antioxidant and antiradical activities [3]. Polyphenols are essentially present in the seed coats and in minor amount in cotyledons.

The beneficial effects of polyphenols on human health are expressed primarily through the reduction of the oxidative stress [4]. Some polyphenols are also able to exert antiapoptotic, antiaging, as well as anticarcinogenic activity, overall inhibiting the cell proliferation processes [5, 6].

Epidemiological studies have shown a strong link between the consumption of legumes and prevention of cancer risk, as well as the reduction of diabetes and cardiovascular risk 
through a normalization of the blood lipid and glucose profile [7]. Wedick et al. (2012) demonstrated that, among flavonoids, higher intakes of anthocyanins could be significantly associated with a lower risk of type 2 diabetes (risk: 0.85) [8].

Legumes are generally eaten without the elimination of the coat and in any case after cooking. Oroian and Escriche (2015) reported the antioxidant effect and total phenolic content of common beans, showing that pigmented beans had generally major antioxidant effect and higher amount of total polyphenols, with respect to the nonpigmented ones [9]. Due to their particular geographical characteristics, the territory of Southern Italy shows many different environments. During the past centuries, local farmers selected various bean seeds after their discovery in South America and diffusion in Europe. A so long activity of selection produced a small number of selected local cultivars, with unique characteristics. Studies regarding the effect of thermal processing on the health relevant functionality of beans are limited, especially with respect to the traditional cultivars present in those areas where the model of the Mediterranean diet is still strong. An improved information of the chemical composition and biological properties of local bean cultivars could help to define and valorise those with a greater nutraceutical potential to suggest to consumers.

Starting from such assumptions, aim of this study was to study the polyphenols (including total flavonoids and anthocyanins), the antioxidant activity, and the antiproliferative activity of the extracts obtained from some nonpigmented, red, speckled, and dark beans endemic ecotypes of Southern Italy. The study was carried out before and after the cooking domestic process.

\section{Materials and Methods}

Twelve varieties of common bean (Phaseolus vulgaris L.) were collected in various rural communities from Campania and Basilicata regions of Southern Italy (Figure 1). Samples were divided into four bean groups based on the colour: nonpigmented beans, red beans, speckled beans, and dark beans; each group included three cultivars (Table 1). Dried beans were stored in the dark prior to extraction.

2.1. Sample Preparation. Samples (10 g) were rehydrated ( $1: 5$, w/v) for 24 hours; the water was discharged and 4 volumes of acetone were added. After $2 \mathrm{~h}$ of incubation at $4^{\circ} \mathrm{C}$ and centrifugation at $11,600 \times \mathrm{g}$ (Biofuge, Beckman, Cassina de Pecchi, Italy), the supernatants were recovered and stored at $4^{\circ} \mathrm{C}$. Pellets were treated again with one volume of acetone and incubated for $1 \mathrm{~h}$ at $4^{\circ} \mathrm{C}$; the two supernatants were pooled, filtered, and, after a complete evaporation, stored at $-20^{\circ} \mathrm{C}$ in the dark, until the analyses were performed [10]. The cooking of beans was performed with deionised water $(1: 5$, $\mathrm{w} / \mathrm{v}$ ), in a home pressure cooker, for $20 \mathrm{~min}$ after the constant output of steam by the pressure safety valve. Cooked beans were immediately cooled, and the extracts were prepared as previously described.

2.2. Total Polyphenol Content. Total polyphenols (TP) of the extracts were determined using the Folin-Ciocalteu colorimetric method, as described by Singleton and Rossi Jr. [11]. Briefly, $50 \mu \mathrm{L}$ of extract was added to $50 \mu \mathrm{L}$ of Folin-Ciocalteu reagent in $800 \mu \mathrm{L}$ of distilled water. The reaction was neutralized with a sodium carbonate solution $(20 \mathrm{~g} / 100 \mathrm{~mL})$. After incubation for $2 \mathrm{~h}$ at room temperature, the absorbance at $\lambda=760 \mathrm{~nm}$ was determined using a Cary UV/Vis spectrophotometer (Varian, Palo Alto, CA, USA). Quantification was based on a standard curve generated using gallic acid. The results were expressed as $\mu \mathrm{g}$ of gallic acid equivalents $(\mathrm{GAE}) / \mathrm{g}$ of $\mathrm{DW}$ samples \pm standard deviation (SD).

2.3. Total Flavonoids. Total flavonoids (TF) were spectrophotometrically determined at $510 \mathrm{~nm}$ following the method of Zhishen et al. [12] with some modifications. The extract $(50 \mu \mathrm{L})$ was added to distilled water followed by $5 \% \mathrm{NaNO}_{2}$ and after $5 \mathrm{~min}$ by $\mathrm{AlCl}_{3} 10 \%$. After further $5 \mathrm{~min}$, the reaction mixture was treated with $0.2 \mathrm{~mL}$ of $1 \mathrm{mM} \mathrm{NaOH}$. Finally, the reaction mixture was diluted to $1 \mathrm{~mL}$ with deionised water and the absorbance was measured at $\lambda=510 \mathrm{~nm}$ (Varian, Palo Alto, CA, USA). TF amounts were expressed as $\mu$ g quercetin equivalents/gram of DW samples \pm standard deviation (SD).

2.4. Anthocyanin Content. The amount of anthocyanins was determined by the differential $\mathrm{pH}$ method [13]. Absorbance was measured in a Cary UV/Vis spectrophotometer (Varian, USA), simultaneously at $\lambda=510 \mathrm{~nm}$ and $\lambda=700 \mathrm{~nm}$ in buffers of $\mathrm{pH} 1.0$ and 4.5, using the formula $A=$ $(A 510-A 700)_{\mathrm{pH} 1.0}-(A 510-A 700)_{\mathrm{pH} 4.5}$. A molar absorption of $26,900 \mathrm{~mol} / \mathrm{cm}$ was used for cyanidin-3-glucoside (molecular weight of $449.2 \mathrm{~g} / \mathrm{mol}$ ). Results were expressed as micrograms of cyanidin-3-glucoside equivalents/g of DW samples \pm standard deviation (SD).

2.5. DPPH Radical-Scavenging Activity. The free radicalscavenging activity was determined using the stable radical 2,2-diphenyl-1-picrylhydrazyl (DPPH assay) [14]. The analysis was performed in microplates by adding $15 \mu \mathrm{L}$ of extract to $300 \mu \mathrm{L}$ of a methanolic DPPH solution $\left(6 \times 10^{-5} \mathrm{M}\right)$. Next, the absorbance at $\lambda=517 \mathrm{~nm}$ was spectrophotometrically measured (Cary $50 \mathrm{MPR}$, Varian, USA). The absorbance of DPPH without antioxidant (control sample) was used for baseline measurements. The scavenging activity was expressed as the 50\% effective concentration (EC50), which was defined as the sample amount (mg) necessary to inhibit DPPH radical activity by $50 \%$ during $60 \mathrm{~min}$ of incubation. These experiments were performed in triplicate, and the results were expressed as the mean values \pm standard deviation.

2.6. Phenol Antioxidant Index (PAOXI). As suggested by Vinson et al. [15] the phenol antioxidant index (PAOXI) can be used to estimate a combined measure of the quality and quantity of antioxidants present in a sample. In this study, it was calculated by dividing the DPPH radical-scavenging activity of the sample ( $\mu \mathrm{mol}$ of DPPH inhibited/mg) for the total phenol concentration (mg/g) [16].

2.7. Chromatographic Analysis. An ACQUITY UltraPerformance LC system (Waters) linked to a PDA 2996 
TABLE 1: Sample classification.

Raw sample

(1a) Not pigmented beans: Bianco Acerra (BA)

Cooked sample

(1b) Not pigmented beans: Dente de Morto (DM)

$\left(1 a^{\prime}\right)$ Not pigmented beans: Bianco Acerra (BAc)

(1c) Not pigmented beans: Volturara (V)

$\left(\mathrm{lb}^{\prime}\right)$ Not pigmented beans: Dente de Morto (DMc)

(2a) Red beans: Cannellino Rosso (CR)

$\left(1 c^{\prime}\right)$ Not pigmented beans: Volturara $(\mathrm{Vc})$

(2b) Red beans: O Russ (OR)

$\left(2 \mathrm{a}^{\prime}\right)$ Red beans: Cannellino Rosso (CRc)

(2c) Red beans: Zampognaro $(\mathrm{Z})$

$\left(2 b^{\prime}\right)$ Red beans: O Russ (ORc)

(3a) Speckled beans: Pettilanculo (P)

(3b) Speckled beans: Sanghellatto (S)

$\left(2 c^{\prime}\right)$ Red beans: Zampognaro $(\mathrm{Zc})$

(3c) Speckled beans: Screziato impalato $(\mathrm{Si})$

(4a) Dark beans: Nero Acerra (NA)

(4b) Dark beans: Nero Frigento (NF)

(4c) Dark beans: Nero Caposele (NC)

$\left(3 \mathrm{a}^{\prime}\right)$ Speckled beans: Pettilanculo (Pc)

$\left(3 b^{\prime}\right)$ Speckled beans: Sanghellatto(Sc)

$\left(3 c^{\prime}\right)$ Speckled beans: Screziato impalato (Sic)

$\left(4 \mathrm{a}^{\prime}\right)$ Dark beans: Nero Acerra (NAc)

$\left(4 \mathrm{~b}^{\prime}\right)$ Dark beans: Nero Frigento (NFc)

Cooked samples are indicated with "c."
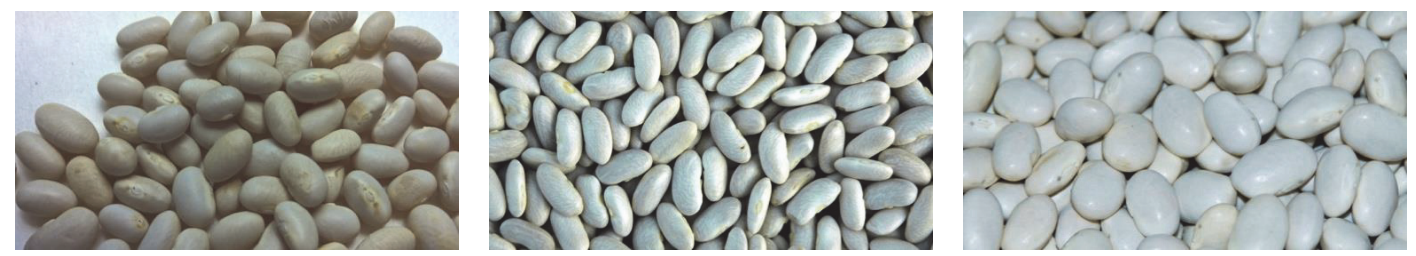

BA-DM-V
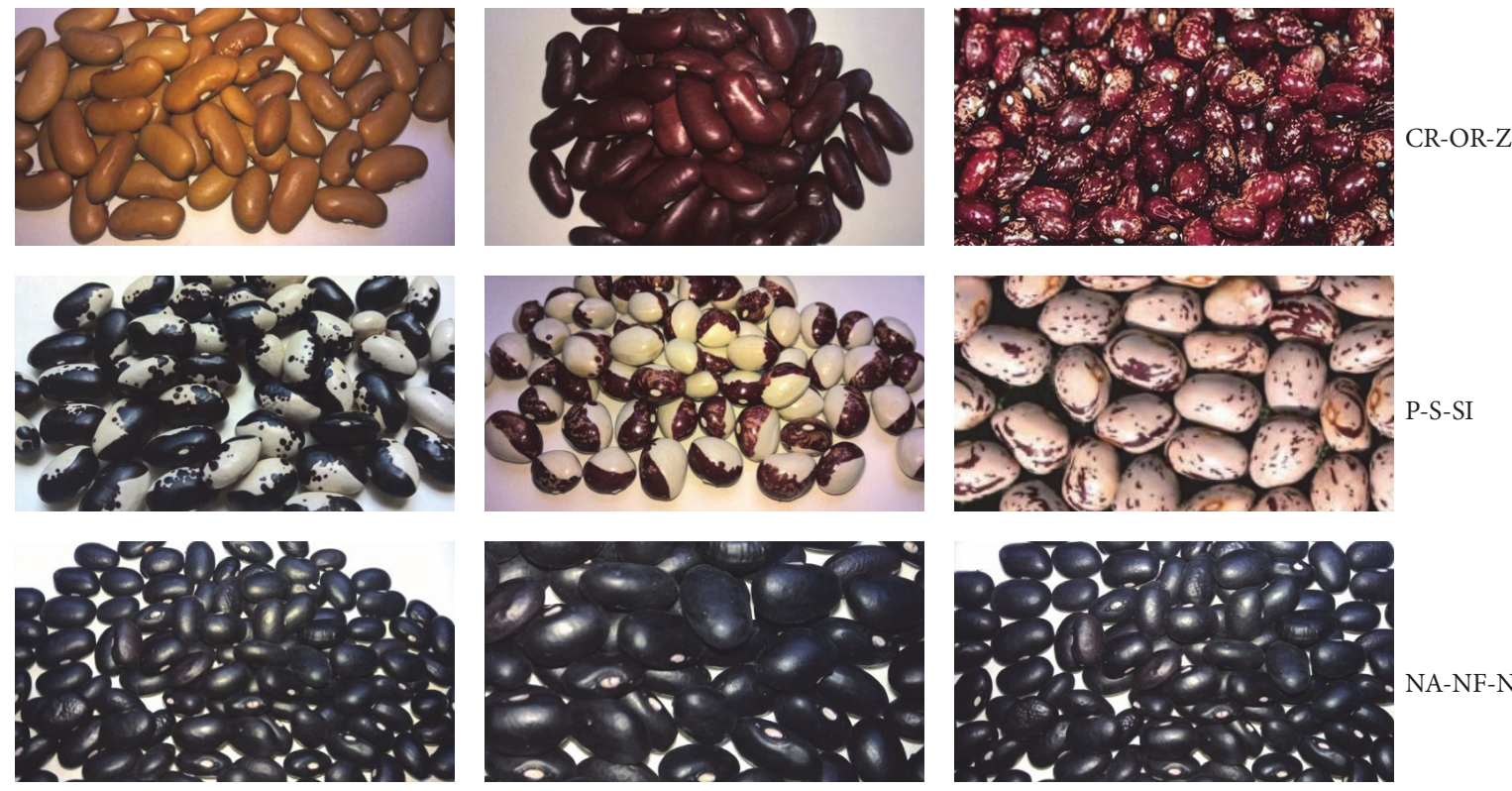

NA-NF-NC

FIGURE 1: Photo of 12 varieties of beans (Phaseolus vulgaris L.) analyzed. Samples were classified into four groups: nonpigmented beans, red beans, speckled beans, and dark beans. Nonpigmented beans: Bianco Acerra (BA), Dente di morto (DM), and Volturara (V). Red beans: Cannellino Rosso (CR), 'O Russ (OR), and Zampognaro (Z). Speckled beans: Pettilanculo (P), Sanghellatto (S), and Screziato impalato (Si). Dark beans: Nero di Acerra (NA), Nero di Frigento (NF), and Nero di Caposele (NC).

photodiode array detector (Waters) was used for ultraperformance liquid chromatography analyses. The Empower software controlled the instruments and acquired and processed the data. The extracts and standards (previously dissolved in methanol) were filtered $(0.45 \mu \mathrm{m}$; Waters) before analysis. The analyses were carried at $30^{\circ} \mathrm{C}$ using a reversed phase column (BEH $\mathrm{C}_{18}, 1.7 \mu \mathrm{m}, 2.1100 \mathrm{~mm}$; Waters) following the method of Fratianni et al. [17]. The mobile phase consisted of solvent A ( $7.5 \mathrm{mM}$ acetic acid) and solvent $\mathrm{B}$ (acetonitrile) at a flow rate of $250 \mu \mathrm{L} \mathrm{min}^{-1}$. Gradient elution was employed, starting with $5 \% \mathrm{~B}$ for $0.8 \mathrm{~min}$; then 5-20\% B over $5.2 \mathrm{~min}$; isocratic $20 \%$ B for $0.5 \mathrm{~min} ; 20-30 \%$ B for $1 \mathrm{~min}$; isocratic $30 \% \mathrm{~B}$ for $0.2 \mathrm{~min} ; 30-50 \%$ B over $2.3 \mathrm{~min}$; $50-100 \%$ B over $1 \mathrm{~min}$; isocratic $100 \%$ B for $1 \mathrm{~min}$; 
and $100-5 \%$ B over $0.5 \mathrm{~min}$. At the end of this process, the system equilibrated the column under the initial conditions for $2.5 \mathrm{~min}$.

\subsection{Determination of In Vitro Cancer Cell Viability}

2.8.1. Cell Culture and Extracts. MCF-7, A549, and Caco-2 cell lines were obtained from the American Type Culture Collection (ATCC, Rockville, MD). Cells were grown in Dulbecco's modified eagle's medium (DMEM) supplemented with $10 \%$ of heat-inactivated foetal bovine serum (FBS), penicillin $\left(0.010 \mathrm{UL}^{-1}\right)$, streptomycin $\left(10 \mathrm{mg} \mathrm{L}^{-1}\right)$, and sodium pyruvate $0.0002 \mathrm{M}$. Cultures were incubated in the presence of $5 \% \mathrm{CO}_{2}$ at $37^{\circ} \mathrm{C}$ and $100 \%$ relative humidified atmosphere. Several concentrations of extract were dissolved in DMEM medium. The culture media were evaluated in terms of $\mathrm{pH}$ and precipitation of components, in order to avoid possible cytotoxic effects due to changes in these factors on the cellular microenvironment. Only the concentrations that did not change the culture media conditions were selected for further assays.

2.8.2. Crystal Violet Assay. The cells were plated $(10 \times$ $10^{3}$ /well) in 48 -well plates in complete medium. After $24 \mathrm{~h}$, the medium was removed and replaced on the first day with the same medium (control) or supplemented with various extracts doses. Cells were observed with an inverted microscope every $24 \mathrm{~h}$, to identify morphological changes, toxicity, or cell death. The percentage of cell proliferation was estimated on the fourth day by a colorimetric assay reported by Kueng et al. [18] modified as follows: cells were fixed for $20 \mathrm{~min}$ at room temperature with $1 \%$ paraformaldehyde (PFA), stained with $0.1 \%$ crystal violet in $20 \%$ methanol for 20 min, washed with PBS, solubilized with $10 \%$ acetic acid, and read at $595 \mathrm{~nm}$ in a microplate reader (Cary $50 \mathrm{MPR}$, Varian, USA). The experimental conditions were tested in triplicate, and separate experiments were performed on at least three separate occasions.

2.8.3.3-(4,5-Dimethylthiazol-2-yl)-2,5-diphenyltetrazolium Bromide (MTT) Reduction Assay. Cells were seeded in 96well microplates at a density of $5 \times 10^{3}$ cells/well and grown for $24 \mathrm{~h}$ at $37^{\circ} \mathrm{C}$ in $5 \% \mathrm{CO}_{2}$ prior to the addition of test samples. The cells were treated with different sample concentrations dissolved in Dulbecco's phosphate buffered saline (PBS). After $48 \mathrm{~h}$ of incubation, cell viability was determined using a colorimetric MTT assay. Cell survival (\%) was measured as the reduction of MTT in formazan at $550 \mathrm{~nm}$. Triton ${ }^{\circledR} \mathrm{X}-$ $100(10 \mu \mathrm{L}$ of $10 \%$ solution) was used as a positive control. Untreated cells (vehicle alone) were chosen as the negative control. The controls and samples were assayed in triplicate for each concentration and replicated three times. The absorbance values were converted into percentages of cell viability using the following formula: Cell viability $=$ Abs sample/Abs control $\times 100$.

2.9. Statistical Analysis. Data were expressed as mean \pm standard deviation of triplicate measurements. Analysis of variance (ANOVA) was used to compare results and significance was accepted at $p<0.05$. The PC software "Excel Statistics" was used for the calculations. Principal Component Analysis (PCA) was used to relate values of biological activities to phenolic composition, using the free software environment for statistical computing and graphics R (https://www.r-project.org/). For cell assays, the EC50 values were calculated using ED50plus v1.0 online software.

\section{Results and Discussion}

3.1. Polyphenol Content. The content of total polyphenols (TP) present in the extracts of beans is shown in Table 2. Results, expressed as $\mu \mathrm{g}$ GAE/gr (dw of seeds), showed significant differences ( $p \leq 0.01$ ) among samples; on the other hand, such differences were not significant $(p>$ 0.05 ) within the same group of beans. Maximal quantitative differences in TP were obtained between the extracts of white beans (ranging from 135.04 to 275.4) and speckled beans (ranging from 1061.9 to 1249.7), with an even ratio of about $1: 10$. In the extracts of red and black beans, values of TP were intermediate, in agreement to the results reported by Heimler et al. [19], which studied other Italian varieties of Phaseolus vulgaris L. An exception was represented by the extract of Cannellino Rosso (CR) (TP = 229.70) which, although belonging to the red group, exhibited an amount of polyphenols comparable to that found in nonpigmented beans. The colour of this variety was more clear compared to the other red beans (Figure 1).

The extracts obtained from the cooked beans showed a lower amount of TP with respect to the corresponding raw samples, except those obtained from the nonpigmented beans, for which the amount of polyphenols remained similar after cooking. For example, taking into consideration the cultivar Bianco di Acerra, the amount of TP remained virtually the same, before and after the thermal treatment (275.442 and 241.782, resp.).

3.2. Determination of Flavonoids. Usually, flavonoids and other phenolic compounds are typically stored in the seed coat due to their antipathogen and antifeeding activities; furthermore, such localization assures the best protection of the seed from external attacks (pathogens, insects, etc.) [20]. Many of the flavonoids that give rise to the coat colour of beans may also provide positive health benefits as antioxidants. This class of polyphenols was present in all samples analysed, being particularly abundant in the coloured beans, with a very similar trend to that of the polyphenols, as shown in Table 2. The extracts of white beans showed a low content of flavonoids, not more than $58.73 \mu \mathrm{g} / \mathrm{QE}$. The highest quantities of flavonoids were found in the extracts of speckled beans as well as in that of the red cultivar ' $O$ Russu (OR). The extracts obtained from the three speckled beans Pettilanculo (P), Sanghellatto (S), and Screziato impalato (SI) showed 925.654 $\mu \mathrm{g} / \mathrm{QE}, 910.551 \mu \mathrm{g} / \mathrm{QE}$, and $703.336 \mu \mathrm{g} / \mathrm{QE}$, respectively; the extract of cultivar Nero di Acerra (NA) was the richest in terms of content in flavonoids among dark beans analysed $(542.337 \mu \mathrm{g} / \mathrm{QE})$.

3.3. Determination of Total Anthocyanins. As expected, a higher content of anthocyanins was observed in the extracts 
TABLE 2: Total polyphenols (PT), antioxidant activity, flavonoids (FT), and anthocyanin contents in the bean extracts. The concentration of total polyphenols was expressed as $\mu$ g equivalents of gallic acid/g of DW sample; antioxidant activity was expressed as EC50 (mg/mL DPPH); flavonoids were expressed as $\mu$ g equivalents of quercetin/g of DW sample; the content of anthocyanin content was expressed as $\mu \mathrm{g}$ equivalents of cyanidin-3-glucoside/g of DW sample. Data are the mean values of three independent experiments ( \pm standard deviation).

\begin{tabular}{|c|c|c|c|c|}
\hline & $\begin{array}{c}\text { Polyphenol } \\
\text { content } \\
(\mu \mathrm{g} \mathrm{GAE} / \mathrm{gr}(\mathrm{DW}))\end{array}$ & $\begin{array}{c}\text { Antioxidant } \\
\text { activity } \\
(\mathrm{mg} \times \mathrm{mL} \text { di DPPH })\end{array}$ & $\begin{array}{c}\text { Flavonoids } \\
\text { content } \\
(\mu \mathrm{g}(\mathrm{QE}) / \mathrm{gr}(\mathrm{DW}))\end{array}$ & $\begin{array}{c}\text { Anthocyanin } \\
\text { content } \\
(\mu \mathrm{g}(\mathrm{C} 3 \mathrm{GE}) / \mathrm{gr}(\mathrm{DW}))\end{array}$ \\
\hline (BA) & $275.442 \pm 58.621$ & $23.619 \pm 0.532$ & $54.733 \pm 3.316$ & 0 \\
\hline$(\mathrm{DM})$ & $135.037 \pm 6.316$ & $55.217 \pm 5.178$ & $58.731 \pm 2.471$ & 0 \\
\hline$(\mathrm{V})$ & $165.524 \pm 12.77$ & $28.826 \pm 2.329$ & $51.511 \pm 1.422$ & 0 \\
\hline$(\mathrm{BA}-\mathrm{c})$ & $241.782 \pm 54.213$ & $61.605 \pm 8.087$ & $50.992 \pm 4.804$ & 0 \\
\hline$(\mathrm{DM}-\mathrm{c})$ & $211.907 \pm 37.017$ & $50.133 \pm 3.786$ & $34.323 \pm 4.798$ & 0 \\
\hline$(\mathrm{V}-\mathrm{c})$ & $126.29 \pm 20.212$ & $66.572 \pm 3.197$ & $49.483 \pm 5.883$ & 0 \\
\hline (CR) & $229.698 \pm 3.909$ & $10.619 \pm 0.211$ & $100.151 \pm 9.367$ & $3.015 \pm 0.691$ \\
\hline (OR) & $1205.446 \pm 23.884$ & $1.722 \pm 0.013$ & $878.749 \pm 58.878$ & $8.864 \pm 0.773$ \\
\hline$(\mathrm{Z})$ & $997.774 \pm 90.482$ & $1.927 \pm 0.036$ & $562.378 \pm 48.128$ & $10.706 \pm 0.561$ \\
\hline$(\mathrm{CR}-\mathrm{c})$ & $182.275 \pm 23.009$ & $27.291 \pm 3.351$ & $116.189 \pm 2.822$ & $1.148 \pm 0.068$ \\
\hline$(\mathrm{OR}-\mathrm{c})$ & $621.338 \pm 27.434$ & $6.022 \pm 0.145$ & $360.417 \pm 4.864$ & $5.323 \pm 0.248$ \\
\hline$(\mathrm{Z}-\mathrm{c})$ & $687.874 \pm 25.338$ & $4.849 \pm 0.045$ & $202.396 \pm 11.1$ & $6.113 \pm 0.763$ \\
\hline (P) & $1249.71 \pm 29.941$ & $1.583 \pm 0.047$ & $925.654 \pm 90.209$ & $6.314 \pm 1.285$ \\
\hline (S) & $1061.935 \pm 13.603$ & $1.568 \pm 0.041$ & $910.551 \pm 137.472$ & $3.629 \pm 0.193$ \\
\hline$(\mathrm{Si})$ & $1150.474 \pm 15.993$ & $1.813 \pm 0.056$ & $703.336 \pm 121.5$ & $7.255 \pm 1.794$ \\
\hline$(\mathrm{P}-\mathrm{c})$ & $607.606 \pm 8.486$ & $5.052 \pm 0.171$ & $332.618 \pm 6.633$ & $2.388 \pm 0.796$ \\
\hline$(\mathrm{S}-\mathrm{c})$ & $565.326 \pm 58.081$ & $3.82 \pm 0.003$ & $192.021 \pm 21.969$ & $1.338 \pm 0.372$ \\
\hline$(\mathrm{Si}-\mathrm{c})$ & $622.14 \pm 74.146$ & $6.253 \pm 0.116$ & $245.306 \pm 22.634$ & $3.963 \pm 0.456$ \\
\hline (NA) & $604.23 \pm 53.995$ & $5.161 \pm 0.352$ & $244.698 \pm 14.524$ & $29.702 \pm 3.327$ \\
\hline$(\mathrm{NF})$ & $601.269 \pm 52.156$ & $4.346 \pm 0.088$ & $293.928 \pm 9.119$ & $18.909 \pm 2.457$ \\
\hline$(\mathrm{NC})$ & $1291.62 \pm 40.16$ & $4.347 \pm 0.609$ & $542.337 \pm 16.454$ & $63.278 \pm 1.547$ \\
\hline$(\mathrm{NA}-\mathrm{c})$ & $359.844 \pm 28.37$ & $7.996 \pm 0.042$ & $112.927 \pm 2.86$ & $5.63 \pm 0.799$ \\
\hline$(\mathrm{NF}-\mathrm{c})$ & $240.553 \pm 23.097$ & $14.528 \pm 0.803$ & $99.694 \pm 4.163$ & $6.939 \pm 0.608$ \\
\hline$(\mathrm{NC}-\mathrm{c})$ & $436.626 \pm 50.194$ & $6.78 \pm 0.041$ & $193.103 \pm 9.974$ & $10.508 \pm 1.206$ \\
\hline
\end{tabular}

of dark beans, while lower amounts were found in those of speckled and red samples, except Zampognaro (Z) bean (10.706 $\mu \mathrm{g}$ C3GE/gram) (Table 2). The extract of the dark bean Nero di Caposele (NC) showed the highest value (63.278 $\mu \mathrm{g}$ C3GE/gram) of anthocyanins; moreover, this cultivar proved to be also the richest with regard to total polyphenols and flavonoids among the dark cultivars analysed. It should be emphasized that the anthocyanins in the beans are exclusively present in the peel [21]. Therefore it is sufficient that the seeds are smaller to obtain a higher anthocyanin value, as we observed in our test as regard as cultivar NC. Cooking lowered the content of anthocyanins present in the samples; however, some cultivars ( $Z$ among speckled and NC among dark cultivars) maintained a content of anthocyanin of $6.11 \mu \mathrm{g}$ C3GE/gram and $10.508 \mu \mathrm{g}$ C3GE/gram, respectively.

3.4. Antioxidant Activity. The antioxidant effects in bean extracts were investigated by DPPH test. Overall, the samples exhibited relevant antioxidant qualities and few $\mathrm{mg}$ of the extracts were sufficient to inhibit at $50 \%$ of the activity of $1 \mathrm{~mL}$ of the free radical DPPH (Table 2). Speckled beans showed the highest antioxidant activity $\left(\mathrm{EC}_{50}\right.$ not exceeding $1.813 \mathrm{mg} / \mathrm{mL}$ ), followed by red beans (except for CR) and black beans $\left(\mathrm{EC}_{50}\right.$ not superior than $5.2 \mathrm{mg} / \mathrm{mL}$ ). As expected, the extracts of nonpigmented varieties exhibited the lowest antioxidant activity (with $\mathrm{EC}_{50}$ values ranging between $23.62 \mathrm{mg} / \mathrm{mL}$ and $55.21 \mathrm{mg} / \mathrm{mL}$ ). Cooked beans, in spite of a loss of total polyphenols, disclosed intriguing results. To estimate the combined measure of the quality and quantity of antioxidants present in the sample, we adopted the so-called phenol antioxidant index (PAOXI) as suggested by Vinson et al. [15]. In our study, such index was calculated by dividing the $\mathrm{DPPH}$ radical-scavenging activity of the sample (expressed in this case as $\mu \mathrm{mol}$ of DPPH inhibited/gram of product) with respect to the total polyphenol concentration $(\mathrm{mg} / \mathrm{g})$. This was possible by converting the values obtained in the antioxidant activity in $\mathrm{mg}$, to $\mu \mathrm{M} \mathrm{DPPH} / \mathrm{mg}$ sample. The highest PAOXI value (36.25) was exhibited by the extract of the speckled bean Sanghellatto (S); therefore, the extract of 
TABLE 3: The phenol antioxidant index (PAOXI) $(\mu \mathrm{mol}$ of DPPH inhibited/mg) by the total phenol concentration $(\mathrm{mg} / \mathrm{g})$. Data are the means values of three independent experiments $( \pm$ standard deviation).

\begin{tabular}{lcc}
\hline & $\begin{array}{c}\text { PAOXI } \\
\text { Raw sample }\end{array}$ & Cooked sample \\
\hline (1a) (BA) & 9.486 & 4.016 \\
(1b) (DM) & 8.081 & 5.687 \\
$(1 c)(V)$ & 12.987 & 7.215 \\
\hline (2a) (CR) & 24.61 & 12.076 \\
(2b) (OR) & 28.71 & 16.05 \\
(2c) (Z) & 31.344 & 18.045 \\
\hline (3a) (P) & 30.187 & 19.574 \\
(3b) (S) & 36.25 & 27.8 \\
(3c) (Si) & 29.002 & 15.434 \\
\hline (4a) (NA) & 19.252 & 20.918 \\
(4b) (NF) & 23.003 & 17.206 \\
(4c) (NC) & 10.709 & 20.297 \\
\hline
\end{tabular}

the dark cultivar Nero di Caposele exhibited the lowest PAOXI value (10.79) among coloured beans (Table 3). This simple calculation could help in clarifying about the relationship between polyphenols and antioxidant activity that is not always so direct.

Although it was possible to establish a clear correlation between the levels of polyphenols and the free radicalscavenging properties of the extracts, we observed some diversity, which could be ascribable to the differences between their components constituting total polyphenols. It is known that there are a variable number of combinations of the compounds for each sample and that the antioxidant potential of these individual components is variable. From the analysis of total polyphenols, total flavonoids, and antioxidant activity, we observed that the extracts of the dark bean Nero di Caposele (NC) showed the highest amount of total polyphenols; however, speckled Screziato impalato bean (SI), although containing slightly less polyphenols, exhibited higher flavonoid content, and its PAOXI index was significantly higher (10.79 versus 29.0$)$. This reinforced the idea that the antioxidant potential could be strongly linked to the content of flavonoids. Cooking affected the antioxidant activity; for some varieties (e.g., NA and NF) the PAOXI values were similar to those obtained before cooking; indeed in some cases (NC) a higher PAOXI index was observed, suggesting that the thermal processing reinforced their antioxidant efficacy.

3.5. Identification of Polyphenols. The UPLC analysis provided an overview of the main phenolic compounds in every sample. In Figure 2 we reported the chromatograms obtained from the extracts of four cultivars of beans, each of which representing a group (white, speckled, red, and dark). For each one, we reported the profiles obtained before and after the process of cooking. Table 4 shows, organised as tabular form, the amount of each polyphenol recognised from the apparatus, on the basis of known standard. The data are separated according to the groups.

The profiles of the extracts of nonpigmented beans were very simple; in fact, we found only few peaks, present in the initial part of the chromatogram. The extract of the variety Dente di Morto DM showed even a minor number of peaks with respect to the other two nonpigmented beans BA and $\mathrm{Q}$ analysed (chromatogram not shown). Despite a few peaks viewable, the sensitivity of the equipment still allowed us to detect and identify several known polyphenols, even if they were present in small quantities in the nonpigmented beans (Table 4(a)). Polyphenol profiles of the extracts of speckled, red, and dark beans were richer and more complete. Some polyphenols were present only in the extracts giving rise from the pigmented beans. For example, myricetin was identified only in the extracts of the pigmented beans: it was present in the extract of raw bean NC $(1.986 \mu \mathrm{g} / \mathrm{gram}$, Table $4(\mathrm{~d}))$ and in the extracts of $Z$ and Si after cooking ( $3.35 \mu \mathrm{g} / \mathrm{gram}$ and $0.218 \mu \mathrm{g} / \mathrm{gram}$, Tables 4 (c) and 4(b), resp.). Overall, our results were in agreement with dosage of polyphenols previously reported for beans, especially as regards flavonoids [22, 23]. We analysed more extensively those flavonoids already reported in literature for their antiproliferative activity [24], and we found appreciable amount of some flavones and/or flavonoids, such as formononetin, genistein, quercetin 3,4diglucoside, spiraeside, and hyperoside, in the extracts of red samples (Table 4(b)). The extract of Cannellino Rosso, while containing a modest amount of total polyphenol with respect to the extracts of the other two red cultivars, exhibited a polyphenol profile absolutely well correlated with respect to the extracts of the other two red varieties. It should also be highlighted that the decrease of total polyphenols after the cooking of beans did not affect the amount of flavonoids, such as genistein and formononetin. Formononetin is a typical bioactive isoflavone of red clover plant with potent pharmacological activities, including antioxidant, antiviral, antitumor, and cardio protective effects [25]. In addition, this isoflavone is capable of inhibiting the proliferation, inducing apoptosis in human cancer cells, such as breast cancer, prostate tumour, and osteosarcoma [26, 27]. A study by HPLC performed on 62 wild and weedy Mexican bean ecotypes identified kaempferol as one of the main flavonoids, assuming that its quantitative variation could be more related to the genotype than to the seed coat colour [28]. In our experiments, flavonols, such as quercetin and kaempferol, were found both in raw and in processed beans. Likewise, we found kaempferol in the extracts of red cultivar Zampognaro $(\mathrm{Z})$ and in those of the two speckled $\mathrm{P}$ and Si cultivars (Tables 4(b) and 4(c)). Kaempferol is one of the phenolic compounds more studied for its antimutagenic and anticarcinogenic activity both in vitro and in vivo [29]; its concentration in P. vulgaris is very variable, ranging from traces $<0.2 \mathrm{mg} / \mathrm{kg}$ (in Tuscany landraces) [30] to $209.4 \mathrm{mg} / \mathrm{kg}$ (in Mexican cultivated varieties) [3]. Our data were more in agreement with the Tuscany varieties [31]. It is to underline the presence of these compounds in cooked beans, so that they can really carry out their nutraceutical properties, above all because the flavonols are not much affected by heat treatment [32]. 

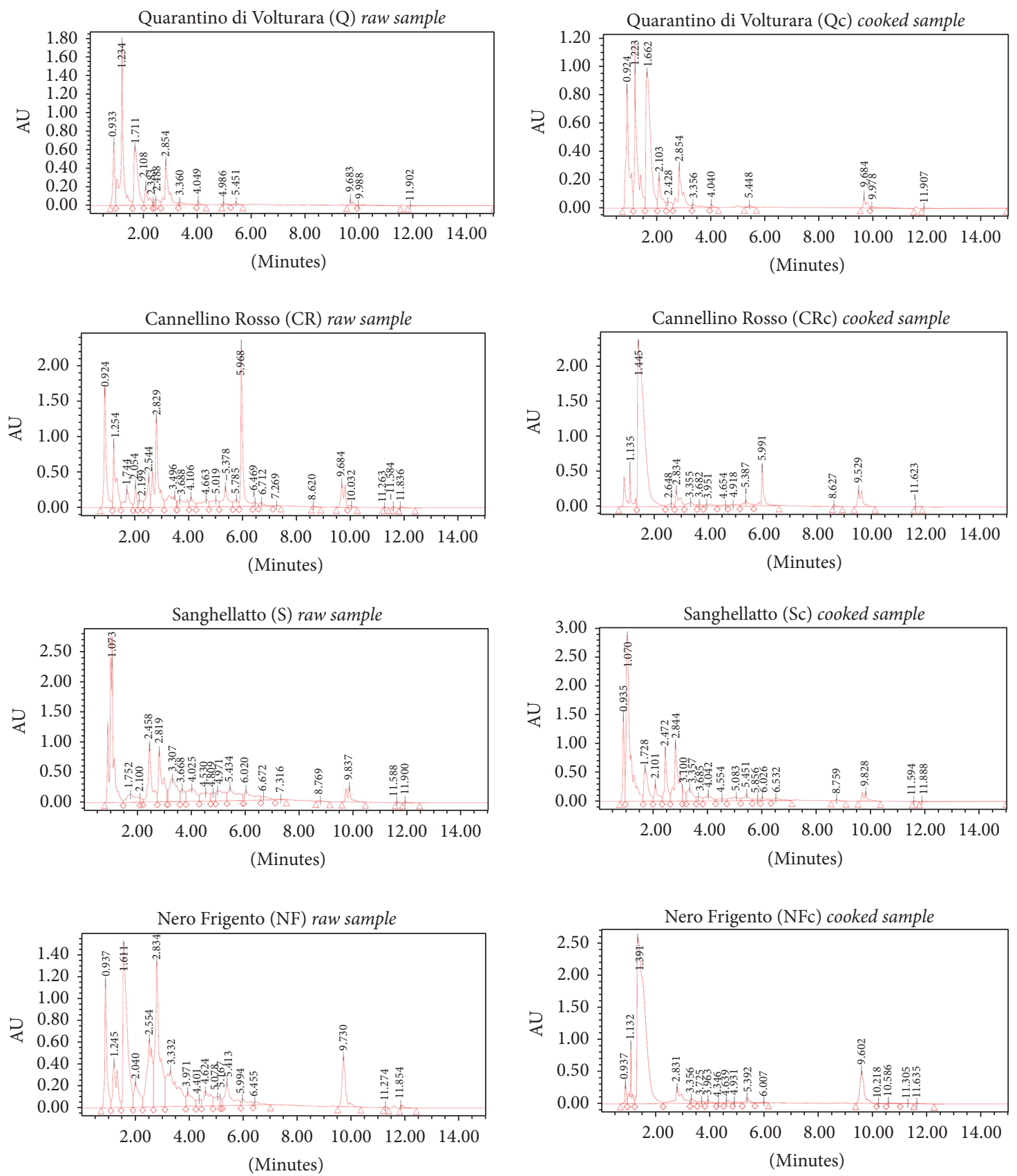

FIGURE 2: UPLC profiles of the polyphenols present into four bean groups: nonpigmented beans Quarantino di Volturara raw and cooked (Q-Qc); red beans Cannellino Rosso raw and cooked (CR-CRc); speckled beans Sanghellatto raw and cooked (S-Sc); and dark beans Nero Frigento raw and cooked (NF- NFc).

The extracts of the three speckled beans, in addition to flavonoids, exhibited many caffeic acid derivatives and an appreciable amount of catechin derivatives, including epigallocatechin (Table 4(c)).

Flavonoids showed a great variability; in fact, besides the formononetin and derivatives of quercetin, they contained also genistein and daidzein, at low amounts. Antiproliferative activity of flavonoids is well known and analysed in many studies [33, 34]. After cooking, the extracts of both Pettilanculo (P) and Sanghellatto (S) showed very high values of formononetin; it is also to underline the presence of spiraeoside in the extract of Sanghellatto after cooking (Sc, Table 4(c)).

The extracts of dark beans gave a well-varied profile, with appreciable values for formononetin and the presence of quercetin glucosides 3-4 (Table 4(d)).

3.6. Anti-Proliferative Activity. The antiproliferative activity of the extracts was evaluated on MCF-7 breast cancer cell line, A549 NSCLC cell line, and Caco-2 colon carcinoma 
TABLE 4: Chromatographic profile of the polyphenols extracts. They were identified based on the retention times of the corresponding standards.

(a)

\begin{tabular}{|c|c|c|c|c|c|c|}
\hline & (1a) (BA) & (1a) (BAc) & (1b) (DM) & (1b) (DMc) & $(1 \mathrm{c})(\mathrm{V})$ & $(1 \mathrm{c})(\mathrm{Vc})$ \\
\hline Gallic acid & 64.563 & 64.827 & 53.168 & 116.329 & 49.236 & 58.734 \\
\hline Caftaric acid & 14.247 & 7.002 & & & 7.907 & 4.021 \\
\hline Chlorogenic acid & 104.362 & 96.367 & 64.453 & 83.111 & 65.225 & 29.6 \\
\hline Epigallocatechin & & 4.087 & & & & \\
\hline Cichoric acid & 11.022 & & & & & \\
\hline Catechin & 10.002 & & & & 9.411 & 6.068 \\
\hline Caffeic acid & & & & 0.539 & & \\
\hline Epicatechin & 2.603 & 2.093 & & 0.824 & 1.807 & 1.16 \\
\hline Sinigrin & & & & 1.779 & 1.939 & \\
\hline Coumaric acid & 1.777 & 1.587 & & & & \\
\hline Hyperoside & 8.83 & 9.08 & 4.532 & 3.453 & 2.536 & 20.823 \\
\hline Spiraeoside & 3.643 & & & & & \\
\hline Formononetin & 26.208 & 66.753 & 6.989 & 1.253 & 2.682 & 4.172 \\
\hline
\end{tabular}

(b)

\begin{tabular}{|c|c|c|c|c|c|c|}
\hline & (2a) (CR) & (2a) (CRc) & (2b) (OR) & $(2 \mathrm{~b})(\mathrm{ORc})$ & $(2 c)(Z)$ & $(2 \mathrm{c})(\mathrm{Zc})$ \\
\hline Gallic acid & 67.565 & 60.985 & 259.764 & 56.526 & 618.536 & 555.525 \\
\hline Caftaric acid & 15.55 & 6.848 & & 6.559 & 49.795 & 33.45 \\
\hline Chlorogenic acid & 76.245 & 35.456 & 308.9 & 67.963 & 132.459 & 82.863 \\
\hline Epigallocatechin & & & & & & 35.165 \\
\hline Cicoric acid & & 21.73 & 160.473 & 35.504 & 117.773 & \\
\hline Catechin & 22.772 & & & & & \\
\hline Vanillic acid & 11.855 & 5.87 & 38.845 & 6.959 & & \\
\hline Epicatechin & 3.27 & 4.4 & 35.573 & 5.926 & 13.191 & 3.373 \\
\hline Quercetin 3,4 diglucoside & & & & 1.941 & 17.595 & \\
\hline 1-3 dicaffeoylquinic acid & & & & 17.311 & & \\
\hline Sinigrin & 5.312 & & & & 16.668 & 1.193 \\
\hline Siringaldeid & 15.045 & & & & & \\
\hline Hyperoside & & 24.541 & 205.9 & 27.281 & 28.773 & 4.323 \\
\hline Taxifolin & 2.48 & & 43.945 & & & \\
\hline Indole3 carboxilic a. & & & & 0.526 & & 0.27 \\
\hline Spiraeosid & & & 295.418 & 10.019 & & \\
\hline Miricetin & & & & & & 0.218 \\
\hline Genistein & 2.09 & 3.651 & & & & \\
\hline Kampherol & & & & & 6.723 & 6.045 \\
\hline Formononentin & 38.648 & 32.289 & 25.736 & 24.985 & 4.986 & 4.063 \\
\hline \multicolumn{7}{|c|}{ (c) } \\
\hline & $(3 a)(P)$ & $(3 \mathrm{a})(\mathrm{Pc})$ & $(3 b)(S)$ & $(3 \mathrm{~b})(\mathrm{Sc})$ & $(3 \mathrm{c})(\mathrm{Si})$ & $(3 \mathrm{c})(\mathrm{Sic})$ \\
\hline Gallic acid & 301.135 & 416.078 & 521.645 & 292.937 & & 428.594 \\
\hline Caftaric acid & 203.988 & 76.12 & 145.791 & 49.122 & 87.6 & 39.629 \\
\hline Chlorogenic acid & 141.223 & 86.658 & 325.264 & 103.334 & 237.473 & 73.644 \\
\hline Epigallocatechin & 27.028 & & & 12.285 & & \\
\hline Cicoric acid & 137.253 & 67.065 & 156.018 & 79.144 & 288.118 & 47.206 \\
\hline Catechin & & & 59.173 & & & \\
\hline Vanillic acid & 62.34 & & 38.509 & & 63.736 & \\
\hline Caffeic acid & & & & & & 2.488 \\
\hline Epicatechin & 21.388 & 9.815 & 34.427 & 8.717 & 56 & \\
\hline Quercetin 3,4 diglucoside & & & 34.809 & & 57.5 & 4.91 \\
\hline 1-3 dicaffeoylquinic acid & 82.608 & & & & & \\
\hline
\end{tabular}


(c) Continued.

\begin{tabular}{|c|c|c|c|c|c|c|}
\hline & (3a) (P) & (3a) $(\mathrm{Pc})$ & $(3 b)(S)$ & $(3 \mathrm{~b})(\mathrm{Sc})$ & $(3 \mathrm{c})(\mathrm{Si})$ & (3c) $(\mathrm{Sic})$ \\
\hline Sinigrin & 47.455 & 12.978 & & 12.793 & 154.191 & \\
\hline Hyperoside & 60.343 & 21.27 & 32.073 & 22.749 & 146.036 & 6.567 \\
\hline Rosmarinic acid & 36.758 & & & & 56.964 & 2.502 \\
\hline Taxifolin & & 14.038 & 9.127 & & & \\
\hline Spiraeosid & 113.72 & & & 39.507 & & \\
\hline Miricetin & & & & & 3.355 & \\
\hline Dadzein & 5.67 & & & & 8.218 & \\
\hline Luteolin & & & & 3.095 & & \\
\hline Quercetin & 8.595 & & & & & \\
\hline Genistein & & 3.732 & & & & \\
\hline Naringenin & & & & 0.622 & & \\
\hline Kampherol & 1.98 & & & & 5.727 & 5.219 \\
\hline Formononentin & 54.108 & 53.785 & 21.373 & 12.951 & 4.527 & 3.642 \\
\hline \multicolumn{7}{|c|}{ (d) } \\
\hline & (4c) (NC) & $(4 \mathrm{c})(\mathrm{NCc})$ & (4b) (NF) & (4b) (NFc) & (4a) (NA) & (4a) (NAc) \\
\hline Gallic acid & 38.359 & 176.217 & 74.851 & 79.488 & 186.945 & 83.053 \\
\hline Caftaric acid & 90.605 & 38.329 & 74.017 & 26.932 & & 41.02 \\
\hline Chlorogenic acid & 334.545 & 122.52 & 178.263 & 94.236 & 752.809 & 166.8 \\
\hline Cicoric acid & & & 153.017 & & & 54.333 \\
\hline Catechin & & & & 7.38 & & \\
\hline Vanillic acid & & & & & 29.8 & \\
\hline Siringic acid & & 0.951 & & 1.296 & & 1.887 \\
\hline Epicatechin & 14.986 & 0.871 & 10.9 & 1.488 & 34.482 & \\
\hline Quercetin 3,4 diglucoside & 45.691 & 5.526 & 11.229 & & & \\
\hline Sinigrin & & & & 1.936 & & \\
\hline Coumaric acid & 6.177 & & 4.377 & & 14.791 & 3.047 \\
\hline Ellagic acid & & & 18.083 & & & \\
\hline Siringaldeid & 30.8 & 4.311 & & & 113.891 & 17.72 \\
\hline Hyperoside & & & 34.506 & 6.68 & & \\
\hline Taxifolin & 13.659 & & & & 21.782 & \\
\hline Indole 3 carboxiladeid & & & & & 5.245 & 1.18 \\
\hline Miricetin & 1.986 & & & & & \\
\hline Genistein & & & & & & 9.467 \\
\hline Formononentin & 35.941 & 28.137 & 39.72 & 5.096 & 163.336 & 65.62 \\
\hline Biochanin-A & & & & & & 4.12 \\
\hline
\end{tabular}

cells using a MTT colorimetric test. After $48 \mathrm{~h}$ of treatment, growth of cells was significantly inhibited in a dosedependent manner, and, for each extract, an EC50 value was calculated from dose-response curves of the cell lines. In Table 3, EC50 values on three cell lines are reported, indicating the concentration of the extracts (expressed as $\mu \mathrm{g}$ equivalent to gallic acid, GAE, as a standard, of total polyphenols present in the extract $/ \mathrm{mL}$ ) able to reduce cell viability by $50 \%$. The extracts of the nonpigmented varieties (BA, DM, and V) did not cause a significant reduction of the cell viability, for each cell line, even at the highest concentration used; the data are not shown and these varieties were not included in Table 5. The EC50 values varied strongly among the three cell lines and the different extracts tested, indicating a different cellular sensitivity to the extracts, as illustrated from the EC50 values. However, the ANOVA analysis on the mean EC50 values obtained for the three cell lines did not return significant $p$ value $(p>0.05)$. The highest EC50 values were measured in A549 cancer cells, using the extract of variety Pettilanculo, while the lowest was found in CaCo- 2 cells, with CR extracts. Generally, the concentrations need to inhibit the proliferation of Caco-2 cells which were 1.06-3.64 folds lower than those of A549 and MCF-7 cells without exception. Overall, the extracts of P and Pc showed only moderate inhibitory effect against the three cancer cell lines, while those of CR and NFc were the most active. In addition, the extracts of cooked beans were less efficient than the correspondent crude extracts, except for Pc, NFc, and $\mathrm{NCc}$, which showed lower EC50 values than the analogous crude extracts. Likely, in these cases, the thermal processing 
TABLE 5: The antiproliferative activity of the extracts on MCF-7, A549, and Caco-2 cells. EC50 values indicate the concentration (expressed as $\mu \mathrm{g}$ equivalent of gallic acid of total polyphenols $/ \mathrm{mL}$ ) able to reduce cell viability by $50 \%( \pm S D)$.

\begin{tabular}{lccc}
\hline & MCF-7 cell line & CaCo-2 cell line & A549 cell line \\
Sample & EC50 & EC50 & EC50 \\
& $\begin{array}{c}\mu \text { GAE mL } \\
( \pm \text { SD })\end{array}$ & $\begin{array}{c}\mu \text { GAE mL }^{-1} \\
( \pm \text { SD })\end{array}$ & $\begin{array}{c}\mu \text { GAE mL } \\
( \pm \text { SD })\end{array}$ \\
\hline CR & $29.40(1.13)$ & $28.52(4.9)$ & $31.32(4.2)$ \\
CRc & $44.17(2.7)$ & $37.49(6.37)$ & $68.79(0.61)$ \\
OR & $128.17(1.17)$ & $58.05(4.16)$ & $130.83(2.92)$ \\
Orc & $135.81(0.54)$ & $77.62(2.23)$ & $121.09(2.84)$ \\
Z & $185.44(2.04)$ & $49.85(6.01)$ & $177.96(0.61)$ \\
Zc & $196.70(1.7)$ & $66.29(3.11)$ & $273.08(4.69)$ \\
P & $333.37(2.3)$ & $186.18(14.11)$ & $377.40(8.34)$ \\
Pc & $115.33(1.6)$ & $72.23(8.72)$ & $252.81(2.28)$ \\
S & $165.57(0.52)$ & $100.17(2.36)$ & $293.62(6.75)$ \\
Sc & $181.36(0.47)$ & $55.65(2.9)$ & $213.27(7.16)$ \\
Si & $102.60(0.84)$ & $44.46(3.73)$ & $122.43(1.5)$ \\
Sic & $158.61(2.7)$ & $76.50(2.39)$ & $88.01(1.15)$ \\
NA & $67.64(1.06)$ & $53.75(1.47)$ & $49.40(0.55)$ \\
NAc & $82.57(0.11)$ & $55.46(2.02)$ & $55.80(1.26)$ \\
NF & $63.75(1.3)$ & $35.79(4.39)$ & $54.0(5.51)$ \\
NFc & $33.6(1.27)$ & $29.4(3.96)$ & $31.92(3.08)$ \\
NC & $119.02(1.69)$ & $73.53(2.36)$ & $118.35(1.63)$ \\
NCc & $107.16(1.03)$ & $52.97(1.87)$ & $49.486(2.56)$ \\
\hline & & &
\end{tabular}

released compounds with inhibitory capacities. Overall, for the same cell line, the values of the inhibition obtained with raw samples were not significantly different with respect to the cooked counterparts.

3.7. Principal Component Analysis. We applied principal component analysis (PCA) to characterize the twelve varieties of beans according to their biological activity. The method was successfully used in the treatment of data in the study of apples [35] and black beans [36]. In our study, seven variables were measured in 24 samples (12 raw and 12 cooked beans), and data were analysed by PCA (Figure 3 ). The cumulative percentage of the total variance explained by the first two components was $84.4 \%$. A bidimensional plot was designed (Figure 3). The distribution of the varieties along PC1 and PC2 showed that samples could be divided into three main groups: group $\mathrm{A}$, which included red varieties and speckled beans positioned near to the centre of the bidimensional plot; group B, which comprised black varieties, and group $\mathrm{C}$, corresponding to exclusively nonpigmented varieties. Group A included beans with the highest concentrations of phenolic compounds and the best antioxidant activity. These varieties differed from the others due to their higher content of total polyphenols, in particular, flavonoids, which were able to influence more effectively both the antioxidant activity and the capability to inhibit the growth of the cancer cells. In fact, we found a positive correlation $(r>$ 0.736) between the total concentration of polyphenols and

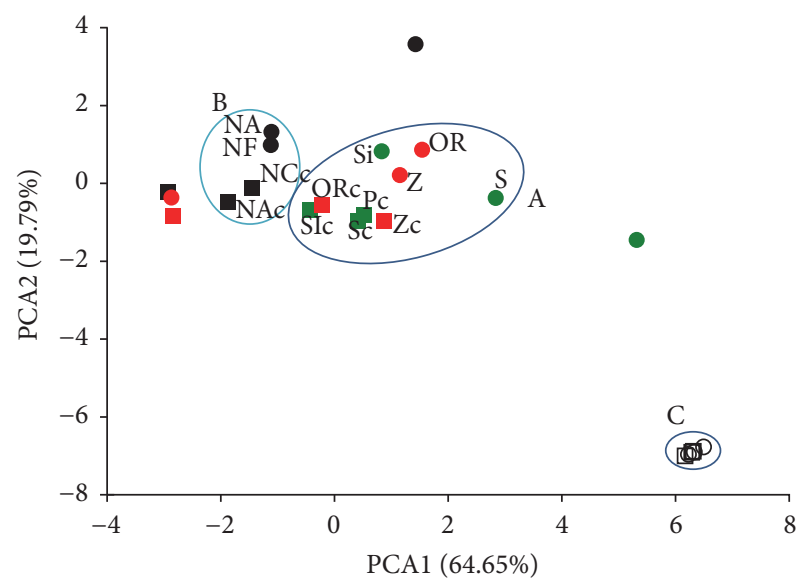

Figure 3: Principal component analysis (PCA): distribution of 12 raw and 12 cooked bean varieties along principal components 1 (PC1) and 2 (PC2). using 7 variables. White circles indicate nonpigmented raw varieties and white squares, nonpigmented cooked varieties. Red circles represent red raw cultivars, red squares for red cooked beans, green circles for speckled raw beans, green squares for speckled cooked beans, black circles for dark raw beans, and black squares for dark cooked beans.

flavonoids and the antioxidant and antiproliferative activities. The highest content of anthocyanins was detected in the extracts of black beans (Table 2). Herein, it is important to underline that such variable contributed to distinguish this group B from the others (Figure 3). Group C included the extracts of nonpigmented beans, which exhibited lower phenolic contents and antioxidant activities correlated to nonsignificant antiproliferative effects.

Our analysis suggested that flavonoids and anthocyanins were accountable for the antioxidant and antiproliferative effects of these extracts. The most active varieties were those belonging to the speckled group. The red varieties were only slightly less active and overlapping with speckled group in PCA. The extracts of dark beans, despite a higher content of anthocyanins, exhibited lower AA values than the speckled, suggesting that the flavonoids were mostly responsible for such biological activity.

\section{Conclusions}

Common beans are a key food of the Mediterranean diet, representing an important source of proteins, fibres, some minerals, vitamins, and bioactive compounds. We evaluated the antioxidant and antiproliferative effects of polyphenolic extracts obtained from old twelve varieties of endemic bean (Phaseolus vulgaris L.), of some rural countries of Southern Italy. Our findings confirm that the speckled, red, and black coloured varieties of beans are more active than the nonpigmented ones. Interestingly, cooking of beans, despite causing a certain loss of bioactive molecules, did not negatively affect in marked way their biological properties. This undoubtedly may represent a result of considerable importance, in order to safeguard and promote the old varieties of beans for their important nutraceutical potential, enhancing their market 
opportunities in the production of functional food and nutraceuticals.

\section{Competing Interests}

The authors declare that there is no conflict of interests regarding the publication of this paper.

\section{Acknowledgments}

This work was partially funded by the Projects "SALVE" and "AGRIGENET," PSR 2007-2013, mis. 214, action f2, of the Campania Regional Council, Italy, as well as by the SAFE SMART Italian Project PON04a2_F, "BE \& SAVE."

\section{References}

[1] H. Kadou and K. Zhou, "Nutraceutical and health properties of common beans (Phaseolus vulgaris)," in Cereals and Pulses: Nutraceutical Properties and Health Benefits, L. L. Yu, R. Tsao, and F. Shahidi, Eds., Wiley, New York, NY, USA, 2012.

[2] I. Hayat, A. Ahmad, T. Masud, A. Ahmed, and S. Bashir, "Nutritional and health perspectives of beans (Phaseolus vulgaris L.): an overview," Critical Reviews in Food Science and Nutrition, vol. 54, no. 5, pp. 580-592, 2014.

[3] L. Díaz-Batalla, J. M. Widholm, G. C. Fahey Jr., E. CastañoTostado, and O. Paredes-López, "Chemical components with health implications in wild and cultivated Mexican common bean seeds (Phaseolus vulgaris L.)," Journal of Agricultural and Food Chemistry, vol. 54, no. 6, pp. 2045-2052, 2006.

[4] L. G. Ranilla, Y.-I. Kwon, M. I. Genovese, F. M. Lajolo, and K. Shetty, "Effect of thermal treatment on phenolic compounds and functionality linked to type 2 diabetes and hypertension management of peruvian and brazilian bean cultivars (Phaseolus vulgaris L.) using in vitro methods," Journal of Food Biochemistry, vol. 34, no. 2, pp. 329-355, 2010.

[5] A. Cardador-Martínez, A. Albores, M. Bah et al., "Relationship among antimutagenic, antioxidant and enzymatic activities of methanolic extract from common beans (Phaseolus vulgaris $\mathrm{L}$ )," Plant Foods for Human Nutrition, vol. 61, no. 4, pp. 161-168, 2006.

[6] N. Kalogeropoulos, A. Chiou, M. Ioannou, V. T. Karathanos, M. Hassapidou, and N. K. Andrikopoulos, "Nutritional evaluation and bioactive microconstituents (phytosterols, tocopherols, polyphenols, triterpenic acids) in cooked dry legumes usually consumed in the Mediterranean countries," Food Chemistry, vol. 121, no. 3, pp. 682-690, 2010.

[7] L. Kan, S. Nie, J. Hu, Z. Liu, and M. Xie, "Antioxidant activities and anthocyanins composition of seed coats from twenty-six kidney bean cultivars," Journal of Functional Foods, vol. 26, pp. 622-631, 2016.

[8] N. M. Wedick, A. Pan, A. Cassidy et al., "Dietary flavonoid intakes and risk of type 2 diabetes in US men and women," American Journal of Clinical Nutrition, vol. 95, no. 4, pp. 925933, 2012.

[9] M. Oroian and I. Escriche, "Antioxidants: characterization, natural sources, extraction and analysis," Food Research International, vol. 74, pp. 10-36, 2015.

[10] F. Fratianni, F. Cardinale, A. Cozzolino et al., "Polyphenol composition and antioxidant activity of different grass pea (Lathyrus sativus), lentils (Lens culinaris), and chickpea (Cicer arietinum) ecotypes of the Campania region (Southern Italy)," Journal of Functional Foods, vol. 7, no. 1, pp. 551-557, 2014.

[11] V. L. Singleton and J. A. Rossi Jr., "Colorimetry of total phenolics with phosphomolybdic-phosphotungstic acid reagents," American Journal of Enology and Viticulture, vol. 16, pp. 144-158, 1965.

[12] J.Zhishen, T. Mengcheng, and W. Jianming, “The determination of flavonoid contents in mulberry and their scavenging effects on superoxide radicals," Food Chemistry, vol. 64, no. 4, pp. 555$559,1999$.

[13] R. E. Wrolstad, Color and Pigment Analyses in Fruit Products, Oregon State University Agricultural Experiment Station Bulletin no. 624, Oregon State University Agricultural Experiment Station, 1976.

[14] W. Brand-Williams, M. E. Cuvelier, and C. Berset, "Use of a free radical method to evaluate antioxidant activity," LWT-Food Science and Technology, vol. 28, no. 1, pp. 25-30, 1995.

[15] J. A. Vinson, Y. Hao, X. Su, and L. Zubik, "Phenol antioxidant quantity and quality in foods: vegetables," Journal of Agricultural and Food Chemistry, vol. 46, no. 9, pp. 3630-3634, 1998.

[16] M. Pelincer Pereira and O. L. Tavano, "Use of different spices as potential natural antioxidant additives on cooked beans (Phaseolus vulgaris). Increase of dpph radical scavenging activity and total phenolic content," Plant Foods for Human Nutrition, vol. 69, no. 4, pp. 337-343, 2014.

[17] F. Fratianni, F. Nazzaro, A. Marandino et al., "Biochemical composition, antimicrobial activities, and anti-quorum-sensing activities of ethanol and ethyl acetate extracts from Hypericum connatum Lam. (Guttiferae)," Journal of Medicinal Food, vol. 16, no. 5, pp. 454-459, 2013.

[18] W. Kueng, E. Silber, and U. Eppenberger, "Quantification of cells cultured on 96-well plates," Analytical Biochemistry, vol. 182, no. 1, pp. 16-19, 1989.

[19] D. Heimler, P. Vignolini, M. G. Dini, and A. Romani, "Rapid tests to assess the antioxidant activity of Phaseolus vulgaris L. dry beans," Journal of Agricultural and Food Chemistry, vol. 53, no. 8, pp. 3053-3056, 2005.

[20] G. Dinelli, A. Bonetti, M. Minelli, I. Marotti, P. Catizone, and A. Mazzanti, "Content of flavonols in Italian bean (Phaseolus vulgaris L.) ecotypes," Food Chemistry, vol. 99, no. 1, pp. 105-114, 2006.

[21] G. R. Takeoka, L. T. Dao, G. H. Full et al., "Characterization of black bean (Phaseolus vulgaris 1.) anthocyanins," Journal of Agricultural and Food Chemistry, vol. 45, no. 9, pp. 3395-3400, 1997.

[22] A. M. Díaz, G. V. Caldas, and M. W. Blair, "Concentrations of condensed tannins and anthocyanins in common bean seed coats," Food Research International, vol. 43, no. 2, pp. 595-601, 2010.

[23] R. F. Zhang, F. X. Zhang, M. W. Zhang et al., "Phenolic composition and antioxidant activity in seed coats of 60 chinese black soybean (Glycine max L. Merr.) varieties," Journal of Agricultural and Food Chemistry, vol. 59, no. 11, pp. 5935-5944, 2011.

[24] P. Batra and A. K. Sharma, "Anti-cancer potential of flavonoids: recent trends and future perspectives," 3 Biotech, vol. 3, no. 6, pp. 439-459, 2013.

[25] Y. Yang, Y. Zhao, X. Ai, B. Cheng, and S. Lu, "Formononetin suppresses the proliferation of human non-small cell lung cancer through induction of cell cycle arrest and apoptosis," International Journal of Clinical and Experimental Pathology, vol. 7, no. 12, pp. 8453-8461, 2014. 
[26] J. Chen, J. Zeng, M. Xin, W. Huang, and X. Chen, "Formononetin induces cell cycle arrest of human breast cancer cells via IGF1/PI3K/Akt pathways in vitro and in vivo," Hormone and Metabolic Research, vol. 43, no. 10, pp. 681-686, 2011.

[27] Y. Ye, R. Hou, J. Chen et al., "Formononetin-induced apoptosis of human prostate cancer cells through ERK1/2 mitogenactivated protein kinase inactivation," Hormone and Metabolic Research, vol. 44, no. 4, pp. 263-267, 2012.

[28] L. G. Espinosa-Alonso, A. Lygin, J. M. Widholm, M. E. Valverde, and O. Paredes-López, "Polyphenols in wild and weedy Mexican common beans (Phaseolus vulgaris L.)," Journal of Agricultural and Food Chemistry, vol. 54, no. 12, pp. 44364444, 2006.

[29] M. G. L. Hertog, P. C. H. Hollman, and M. B. Katan, “Content of potentially anticarcinogenic flavonoids of 28 vegetables and 9 fruits commonly consumed in The Netherlands," Journal of Agricultural and Food Chemistry, vol. 40, no. 12, pp. 2379-2383, 1992.

[30] R. Perazzini, D. Leonardi, S. Ruggeri, D. Alesiani, G. D'Arcangelo, and A. Canini, "Characterization of Phaseolus vulgaris L. landraces cultivated in Central Italy," Plant Foods for Human Nutrition, vol. 63, no. 4, pp. 211-218, 2008.

[31] A. Romani, P. Vignolini, C. Galardi, N. Mulinacci, S. Benedettelli, and D. Heimler, "Germplasm characterization of Zolfino landraces (Phaseolus vulgaris L.) by flavonoid content," Journal of Agricultural and Food Chemistry, vol. 52, no. 12, pp. 38383842, 2004.

[32] C. Ewald, S. Fjelkner-Modig, K. Johansson, I. Sjöholm, and B. Åkesson, "Effect of processing on major flavonoids in processed onions, green beans, and peas," Food Chemistry, vol. 64, no. 2, pp. 231-235, 1999.

[33] K. Yanagihara, A. Ito, T. Toge, and M. Numoto, "Antiproliferative effects of isoflavones on human cancer cell lines established from the gastrointestinal tract," Cancer Research, vol. 53, no. 23, pp. 5815-5821, 1993.

[34] E. J. Choi and G.-H. Kim, "Antiproliferative activity of daidzein and genistein may be related to ER $\alpha / \mathrm{c}$-erbB-2 expression in human breast cancer cells," Molecular Medicine Reports, vol. 7, no. 3, pp. 781-784, 2013.

[35] A. T. Serra, R. O. Duarte, M. R. Bronze, and C. M. M. Duarte, "Identification of bioactive response in traditional cherries from Portugal," Food Chemistry, vol. 125, no. 2, pp. 318-325, 2011.

[36] D. Guajardo-Flores, S. O. Serna-Saldívar, and J. A. GutiérrezUribe, "Evaluation of the antioxidant and antiproliferative activities of extracted saponins and flavonols from germinated black beans (Phaseolus vulgaris L.)," Food Chemistry, vol. 141, no. 2, pp. 1497-1503, 2013. 


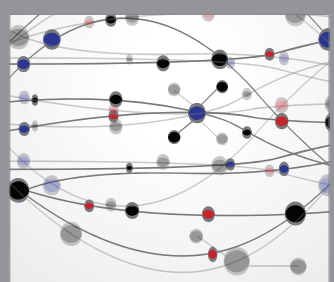

The Scientific World Journal
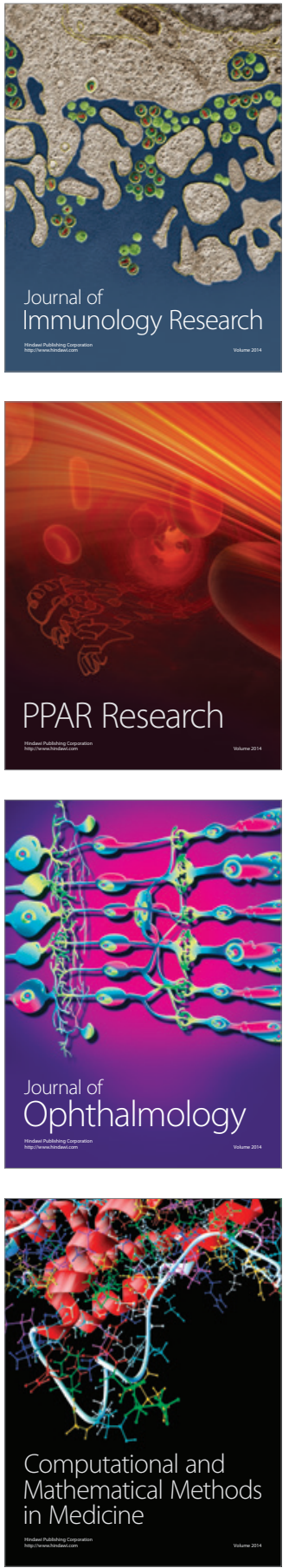

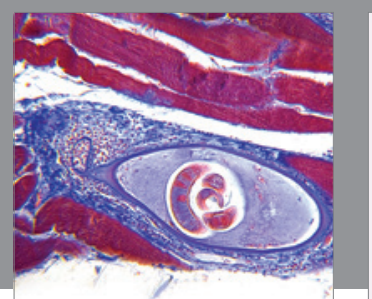

Gastroenterology Research and Practice

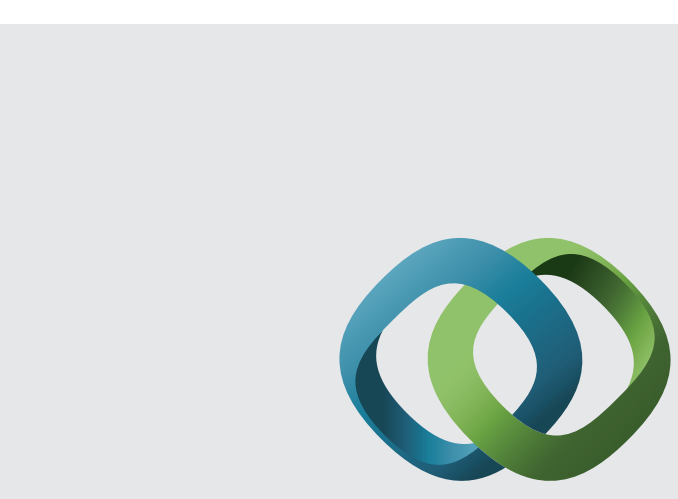

\section{Hindawi}

Submit your manuscripts at

http://www.hindawi.com
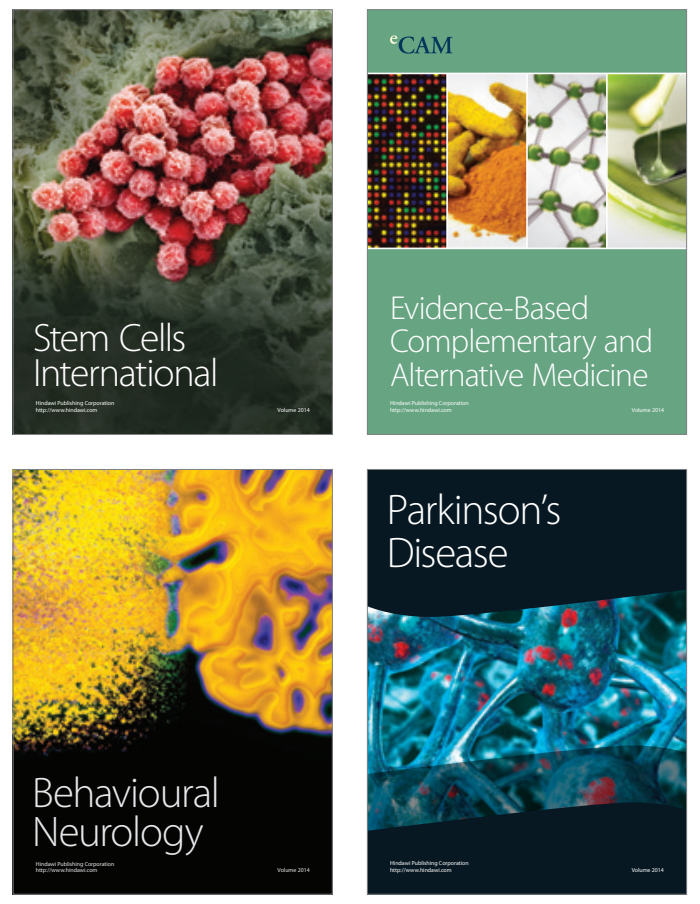
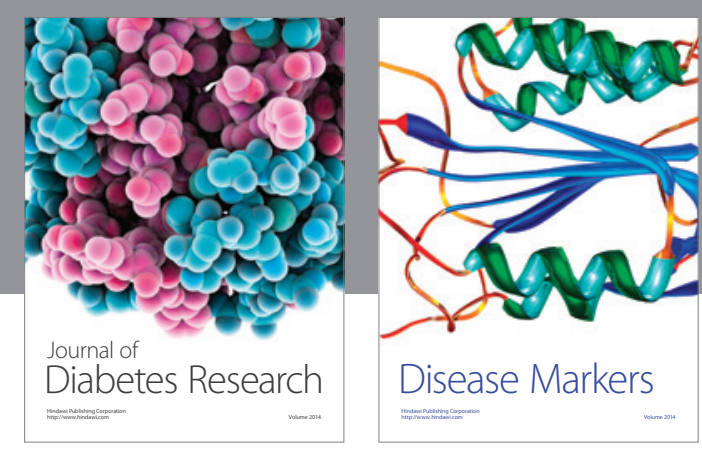

Disease Markers
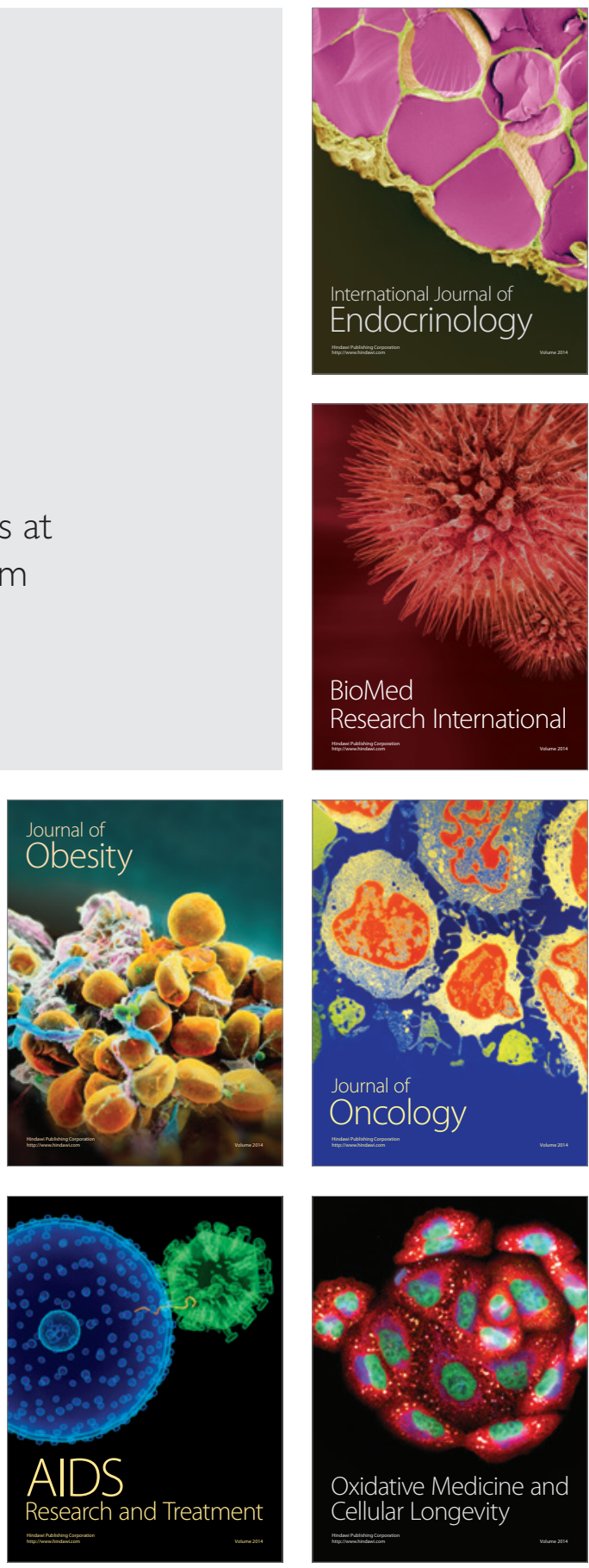